Scrub Weeds and Forestry

\title{
SOME ASPECTS OF SEED ECOLOGY OF GORSE
}

\author{
G. W. IVENS
}

Agronomy Department, Massey University, Palmerston North

Summary

Clearing gorse thicket in February 1976 resulted in a flush of germination producing 200 seedlings $/ \mathrm{m}^{2}$ by May, slowing as grass covered the plots to reach $350 / \mathrm{m}^{2}$ by June 1977 , when seedling mortality had risen to $41 \%$. In uncleared thicket germination was slower, reaching $170 / \mathrm{m}^{2}$ by June 1977 with a mortality of $70 \%$. The reservoir of seed in the soil totalled $10,000 / \mathrm{m}^{2}$, about half in the litter or topmost $2.5 \mathrm{~cm}$, though some seeds occurred to $15 \mathrm{~cm}$. The annual seed deposit was $500-600 / \mathrm{m}^{2}$. Seedlings in the shade become very etiolated and dry matter production was less than $1 \%$ of that in the open.

\section{INTRODUCTION}

Gorse is a prolific seeder and the hard-coated seed may lie dormant in the soil for 26 years (Moss 1959) or possibly longer, providing a reservoir for re-infestation of cleared land. The germination and establishment of gorse seedlings is particularly evident when a dense infestation of mature bushes is cleared and successful control of such seedlings is the key factor in establishing pasture on cleared land. Thompson (1974) studied the survival of gorse sown in association with pasture species but there appear to have been no studies on the development of naturally occurring gorse seedling populations in the field. The present experiment was started with the aim of obtaining a better understanding of the factors involved in the survival or death of gorse seedlings emerging after clearing under field conditions.

\section{METHOD}

An area of dense 4-5 $\mathrm{m}$ tall gorse thicket on a sloping site near Palmerston North at an altitude of $140 \mathrm{~m}$ was cut by hand on 11-18 February 1976. The cut bushes were removed and the area marked into 6 $\mathrm{x} 4.5 \mathrm{~m}$ plots, on some of which the litter (averaging $26,500 \mathrm{~kg} \mathrm{DM} / \mathrm{ha}$ ) was left, while it was raked off others. After removal of the gorse the ground was virtually bare of vegetation. Within each of three replicate raked and unraked plots a $1 \mathrm{~m}^{2}$ subplot was marked out and, at intervals, gorse seedlings were marked as they emerged with numbered plastic labels inserted into the ground alongside. When the numbers emerging between labellings exceeded about $50 / \mathrm{m}^{2}$ the sampling area was further reduced to $0.5,0.2$ or $0.1 \mathrm{~m}^{2}$; the total number of labelled seedlings per plot eventually averaged about 80 . At each observation seedlings already labelled were assessed for condition and heights were measured.

To provide a comparison with the cleared area, similar observations were made on raked and unraked plots within the thicket. In these areas the canopy of the gorse bushes was left intact as far as possible though some clearing of lower, mostly dead branches was needed to allow access.

The experimental area was fenced to exclude livestock but traces of opossums were frequent. No pasture seeds were sown but the cleared plots

Proc. 31st N.Z. Weed and Pest Control Conf. 
developed a cover of grasses, principally creeping fog (Holcus mollis) and sweet vernal (Anthoxanthum odoratum). Scotch thistle (Cirsium vulgare) seedlings also appeared on some plots at an early stage but in small numbers compared with gorse.

Gorse seed numbers in the soil were determined by carefully removing $2.5 \mathrm{~cm}$ layers of soil down to $15 \mathrm{~cm}$ over $0.1 \mathrm{~m}^{2}$ areas situated in both cleared and uncleared parts of the site. Seed was extracted by floating off the light litter in water and washing the fine soil particles through a $1.8 \mathrm{~mm}$ sieve. The material left in the sieve was dried, the chaff separated in a seed blower and the seed finally separated from stones and soil clods by floating off in carbon tetrachloride. Estimates were also made of the numbers of seeds deposited annually in thicket adjacent to the cleared area by collecting the seed in $0.25 \mathrm{~m}^{2}$ gauze-bottomed trays arranged in groups of four.

\section{RESULTS}

Observations on the reservoir of seeds at different depths in the soil are given in Table 1, together with the figures on the numbers of seeds deposited on the ground. The results show that there were an average of 10,000 seeds $/ \mathrm{m}^{2}$ on the experimental site, with approximately $50 \%$ in the litter or the top $2.5 \mathrm{~cm}$ of soil and $75 \%$ in the topmost $5 \mathrm{~cm}$. The annual seed fall was of the order of $500-600 / \mathrm{m}^{2}$. As might be expected from the very variable nature of gorse (some bushes seeding profusely while others produced very little) the seed numbers recorded also varied widely. Individual sample totals from the soil ranged from $1400-17000 / \mathrm{m}^{2}$ while in individual collecting trays the numbers ranged from $180-950 / \mathrm{m}^{2}$ in the first and from $170-1620 / \mathrm{m}^{2}$ in the second year.

TABLE 1: Numbers of gorse seeds extracted from the soil and collected at the surface.

\begin{tabular}{|c|c|c|c|}
\hline \multicolumn{2}{|c|}{$\begin{array}{l}\text { Seed reserves in soil July } 1976 \\
\text { (mean of } 6 \times 0.1 \dot{\mathrm{m}}^{2} \text { samples) }\end{array}$} & \multicolumn{2}{|c|}{$\begin{array}{l}\text { Numbers of seeds deposited } \\
\text { (mean of } 7 \times 1 \mathrm{~m}^{2} \text { samples) }\end{array}$} \\
\hline Layer & No. $/ \mathrm{m}^{2}$ & Period & No. $/ \mathrm{m}^{2}$ \\
\hline $\begin{array}{l}\text { Litter } \\
0-2.5 \mathrm{~cm} \\
2.5-5 \mathrm{~cm} \\
5-7.5 \mathrm{~cm} \\
7.5-10 \mathrm{~cm} \\
10-12.5 \mathrm{~cm} \\
12.5-15 \mathrm{~cm}\end{array}$ & $\begin{array}{r}1210 \pm 940 \\
4160 \pm 2330 \\
2190 \pm 2040 \\
1400 \pm 1460 \\
650 \pm 710 \\
300 \pm 420 \\
90 \pm 100\end{array}$ & $\begin{array}{l}\text { June } 1976 \text { - June } 1977 \\
\text { June } 1977 \text { - March } 1978\end{array}$ & $\begin{array}{l}505 \pm 291 \\
604 \pm 492\end{array}$ \\
\hline Total & $10000 \pm 7530$ & & \\
\hline
\end{tabular}

The numbers of seeds germinating and of surviving seedlings on the cleared and uncleared areas are shown in Fig. 1 as means of the figures for the raked and unraked plots. Temperature and rainfall figures from a meteorological site $4.5 \mathrm{~km}$ away are also given.

It will be seen that, after clearing in mid-February, germination started in March and proceeded rapidly in April and May. With the low winter temperatures in June and July the numbers of new seedlings appearing declined and the decline continued in August and September. Grass seedlings appeared on the plots in the autumn but remained small until early spring. By September most plots bore a dense growth of grass seedlings up to $6 \mathrm{~cm}$ high which thereafter grew rapidly. There was a slight 


\section{Scrub Weeds and Forestry}

increase in gorse germination in the spring but, as the plots became more densely covered with grass in the summer the numbers emerging remained small until the final observation in June 1977.

FIG. 1: Numbers of gorse $/ \mathrm{m}^{2}$ germinating and surviving on cleared and uncleared plots after clearing in Feb. 1976 (means of 3 replicate raked and unraked plots). Mean monthly air temperatures and rainfall shown below.

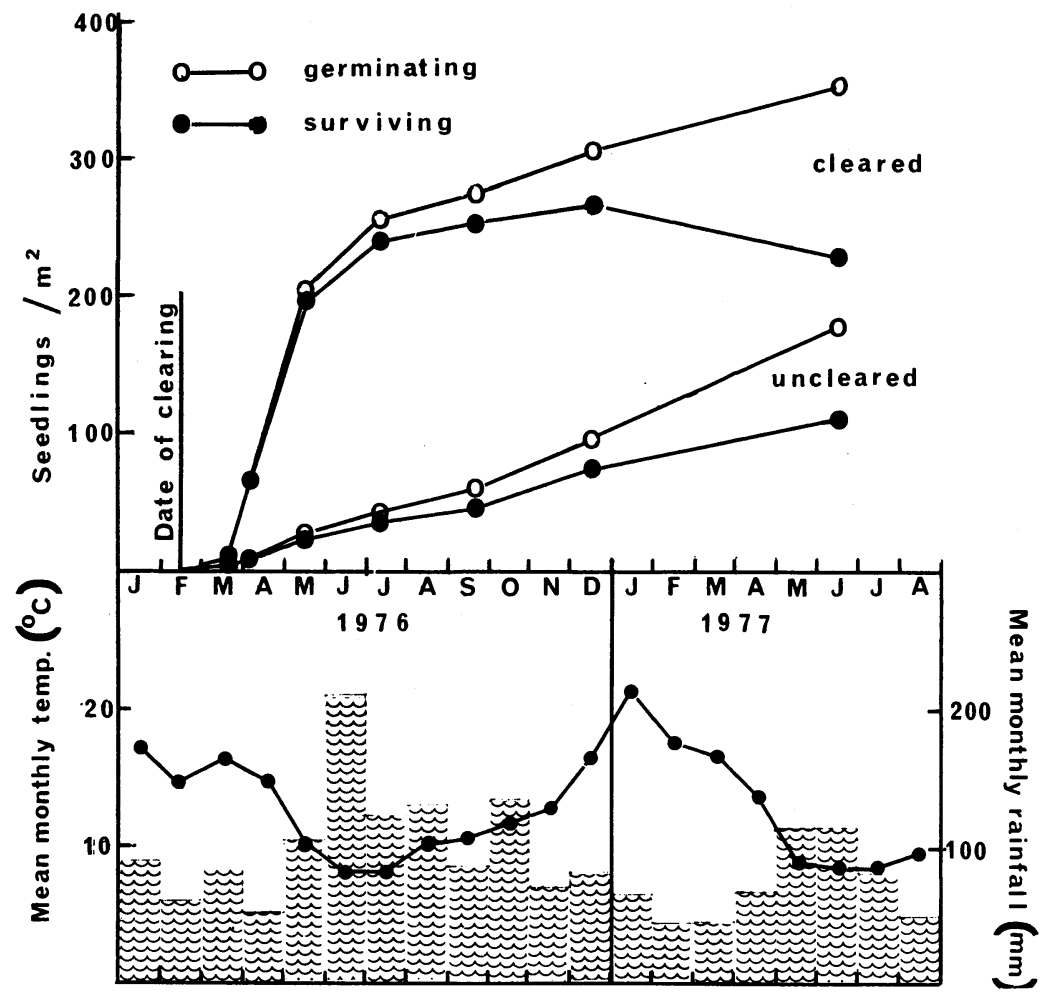

Few seedlings died in the 3 months after germination started but from June onwards the mortality rate gradually increased. By July $7 \%$ of the emerged seedlings had died and the proportion rose to $14 \%$ by December, after which the numbers dying exceeded the numbers of new seedlings so that by June 1977 the overall mortality was $41 \%$.

In the shade of the uncut bushes the rate of seedling emergence was initially lower than on the cleared plots but remained relatively constant. The proportion of emerged seedlings dying was higher throughout the year than in the open (20\% in July 1976 rising to $70 \%$ by June 1977). The causes of death included washing away, burial by debris and, especially with cotyledon stage seedlings in winter, defoliation below the cotyledons, probably by slugs. On the shaded plots many of the seedlings that died became very etiolated and suffered from fungal attack. Over the 16 month period of the experiment the number of seedlings on the uncleared plots 
Scrub Weeds and Forestry

gradually increased and by June 1977 was much higher than the number present at the start. Over the same period a sparse growth of grass and weed seedlings also developed suggesting that, although the gorse bushes were not cut down, the operation of opening up the thicket enough to permit entry was enough to cause an appreciable reduction in shading.

Measurements of seedling height summarised in Table 2 show that there was little difference between the cleared and uncleared plots initially but that the differences increased with time. In the shade the seedlings that survived became spindly and weak-stemmed so that, although a moderate number of seedlings were present, the dry weight per unit area was less than one percent of that on the cleared plots.

TABLE 2: Mean heights $(\mathrm{cm})$ of gorse seedlings on cleared and uncleared plots and final dry weights at conclusion of experiment

\begin{tabular}{lccccc}
\hline & \multicolumn{2}{c}{ Cleared } & & \multicolumn{2}{c}{ Uncleared } \\
\cline { 2 - 3 } \cline { 5 - 6 } & $\begin{array}{c}\text { All } \\
\text { seedlings }\end{array}$ & $\begin{array}{c}\text { Oldest } \\
\text { group of } \\
\text { seedlings }\end{array}$ & & $\begin{array}{c}\text { All } \\
\text { seedlings }\end{array}$ & $\begin{array}{c}\text { Oldest } \\
\text { group of } \\
\text { seedlings }\end{array}$ \\
\hline May 1976 & 0.7 & 2.5 & & 0.5 & 1.6 \\
July 1976 & 1.4 & 2.8 & & 0.6 & 2.0 \\
September 1976 & 1.4 & 2.9 & & 0.8 & 2.2 \\
December 1976 & 5.6 & 7.8 & & 2.2 & 5.0 \\
June 1977 & 17.6 & 26.2 & & 2.0 & 10.1 \\
Final dry weight $\left(\mathrm{g} / \mathrm{m}^{2}\right)$ & 85 & & & 0.75 & \\
June 1977 & & & & & \\
\hline
\end{tabular}

For the sake of clarity the seedling numbers are shown in Fig. 1 as means of the raked and unraked plots. On the cleared area there was a considerable difference between the two, the numbers on the raked plots being only about half those where the litter was left. On the uncleared plots the numbers were greater with raking than without, though the difference was smaller (and not significant at $P<5 \%$ in an analysis carried out on $\sqrt{ } x$ transformed figures).

\section{DISCUSSION}

The gorse bushes on the experimental area were thought to be about 20 years old but the earlier history of the site is not known. From the fact that the soil seed reservoir was $10,000 / \mathrm{m}^{2}$ while the annual deposit was $500-600 / \mathrm{m}^{2}$ it is clear that the soil population had been building up for a considerable time. This is also indicated by the fact that some seeds had penetrated to a depth of at least $15 \mathrm{~cm}$. The rate at which buried, non-germinating seed loses its viability is not known but the observations suggest that the number of seeds germinating in dense thicket was of the order of $130 / \mathrm{m}^{2}$ annually. After clearing larger numbers germinated $\left(520 / \mathrm{m}^{2}\right.$ in 16 months on the unraked plots) but this represented a very small fraction of the total present so that the potential for many years germination remained.

The observations have shown that large numbers of gorse seeds can germinate without the stimulus of burning. However, the reason for the post-clearing flush of germination remains obscure. The most obvious change after clearing is the increased light intensity. Observations by Zabkiewicz (pers comm), however, suggest that light is not essential for 


\section{Scrub Weeds and Forestry}

gorse seed germination. Another possibility is that clearing exposes the seeds to greater temperature fluctuations which might be expected to stimulate germination. It was hoped that the comparison between plots with and without litter might throw some light on this aspect. The main result of raking on the cleared plots, however, appeared to have been merely the removal of a proportion of the most readily germinating seeds. With the re-establishment of a grass cover germination declined again to a low level, possibly because the supply of readily germinating seeds was exhausted or because of the re-establishment of the conditions which inhibited germination before clearing.

In uncleared gorse, although moderate numbers of seeds germinated, a larger proportion of seedlings died and the growth of the remainder was reduced in comparison with those on cleared plots. The reduction involved seedling height and, to a much greater extent, their dry matter production so that in dense shade they became etiolated, weak and susceptible to fungus attack. Thompson (1974) has identified a fungus killing gorse seedlings shaded by clover as a Rhizoctonia species.

On the cleared areas, although gorse made slow growth at first, the seedlings were sturdy and well established before grasses covered the plots. They were thus well able to compete through the spring and early summer and a proportion of seedlings kept pace with the grass growth. During the period December 1976 - June 1977, however, when grass growth reached a maximum, subsequently became flattened and then started to decay, the stress on the gorse seedlings appears to have increased and the total numbers declined. It was not possible to continue observations after this stage as locating the labelled plants resulted in too much disturbance.

The results indicate that even when pasture species are not sown after clearing and such volunteers as Holcus spp. come in relatively slowly, gorse seedling numbers decline when the level of competition becomes high enough. The decline is only gradual, however, and in the present experiment enough seedlings were expected to survive to maintain the infestation. In practice cleared areas are normally oversown with species which provide a cover rapidly and would be expected to compete with gorse seedlings earlier, presumably reducing the rate of survival. It remains uncertain whether a higher measure of gorse seedling control would be provided by introducing livestock, thereby reducing competition from the grass at the same time as the gorse is checked, or by leaving the grass ungrazed, in which case the gorse would not suffer grazing damage but would be subject to increased competition.

\section{ACKNOWLEDGEMENTS}

The author wishes to acknowledge the cooperation of $\mathrm{Mr} \mathrm{R}$. W. Garden who provided the experimental site and of Mr D. Fernandes who assisted with the field work. The study forms part of a project financed by a Ministry of Agriculture and Fisheries Research Grant.

\section{REFERENCES}

Moss, G R 1960. Gorse a weed problem of thousands of acres of farm land. N.Z. J. Agric., 100: 561-567.

Thompson, A., 1974. The effect of fertilisers and pasture competition on gorse growth and establishment. Proc. 27th N.Z. Weed and Pest Control Conf.: 6-10. 